Wstęp: Guzy neuroendokrynne grasicy to bardzo rzadkie nowotwory, stanowiące 2-4\% guzów śródpiersia. Opisywane są przypadki ektopowego wydzielania hormonów w przebiegu tej patologii, z czego zespół ektopowego wydzielania ACTH jest najczęstszą endokrynopatią. W pracy zaprezentowano przypadek zespołu nieadekwatnego wydzielania wazopresyny w przebiegu tego nowotworu.

Opis przypadku: U 55-letniego mężczyzny na rutynowo wykonanym zdjęciu rentgenowskim klatki piersiowej wykryto guz śródpiersia. Po badaniu tomograficznym klatki piersiowej i badaniu PET-CT pacjenta skierowano na leczenie operacyjne, wycięto guz ze śródpiersia o wymiarach $11 \times 8 \times 4 \mathrm{~cm}$, który naciekał płuco lewe i osierdzie. Badanie histopatologiczne wykazało raka neuroendokrynnego grasicy. Z uwagi na wznowę chorego poddano chemioterapii, a następnie leczono analogami somatostatyny z uwagi na pozytywny wynik scyntygrafii receptorowej i aktywność hormonalną nowotworu dającą zespół rakowiaka. W trakcie terapii hormonalnej wykryto zespół nieadekwatnego wydzielania wazopresyny. Dyskusja: Przeprowadzono krótką charakterystykę zespołu nieadekwatnego wydzielania wazopresyny oraz raków neuroendokrynnych grasicy, uwzględniając sposoby leczenia tych jednostek chorobowych. W przypadku guzów o zachowanej ekspresji receptorów somatostatynowych należy brać pod uwagę możliwość zastosowania analogów somatostatyny w formie terapii przewlekłej.

Słowa kluczowe: guzy neuroendokrynne, grasica, zespół nieadekwatnego wydzielania wazopresyny.

\section{Zastosowanie lanreotydu w przypadku guza neuroendokrynnego grasicy z zespołem nieadekwatnego wydzielania wazopresyny}

\author{
Paweł Gut ${ }^{1}$, Jakub Fischbach ${ }^{1}$, Daria Baszko-Błaszyk ${ }^{1}$, Marta Fichna, ${ }^{1,2}$ \\ Maria Gryczyńska ${ }^{1}$, Marek Ruchała ${ }^{1}$
}

${ }^{1}$ Katedra i Klinika Endokrynologii Przemiany Materii i Chorób Wewnętrznych Uniwersytetu Medycznego im. Karola Marcinkowskiego w Poznaniu, Polska 2Instytut Genetyki Człowieka Polskiej Akademii Nauk, Poznań, Polska

\section{Wstęp}

Guzy neuroendokrynne grasicy są niezwykle rzadkimi nowotworami. Stanowią jedynie 2-4\% wszystkich nowotworów wywodzących się ze śródpiersia przedniego [1, 2]. Podobną częstość występowania notuje się w stosunku do wszystkich guzów neuroendokrynnych [2]. Rosai i Higa w latach 70. XX w. pierwsi wykazali istnienie guzów neuroendokrynnych w grasicy i wyodrębnili je z częściej spotykanych guzów tego narządu (grasiczaki) [3]. W literaturze światowej opisywane są przypadki ektopowego wydzielania hormonów przez te nowotwory, z których zespół ektopowego wydzielania ACTH powodujący chorobę Cushinga jest najczęstszą endokrynopatią związaną z tym nowotworem [4]. W dostępnym piśmiennictwie nie znaleziono żadnego opisu przypadku guza neuroendokrynnego grasicy z zespołem nieadekwatnego wydzielania wazopresyny.

\section{Opis przypadku}

U pacjenta, lat 55, w trakcie rutynowo wykonywanych okresowych badań na zdjęciu rentgenowskim klatki piersiowej wykryto guz śródpiersia. W wykonanej tomografii komputerowej stwierdzono przysercowo po stronie lewej hipodensyjną masę o wymiarach $95 \times 87 \times 70 \mathrm{~mm}$ schodzącą poniżej łuku aorty wzdłuż lewej komory serca, ulegającą wzmocnieniu kontrastowemu po podaniu środka cieniującego (ryc. 1.). Badanie PET-CT wykazało aktywny metabolicznie guz śródpiersia prawdopodobnie z przerzutami do węzłów chłonnych bez cech przerzutów odległych. Wykonano lewostronną torakotomię z resekcją guza śródpiersia wraz z nacieczonym płatem górnym płuca lewego i częścią osierdzia. Histopatologiczne badanie śródoperacyjne sugerowało nowotwór złośliwy grasicy. Guz o wymiarach $11 \times 8 \times 4 \mathrm{~cm}$ ogniskowo naciekający płuco poprzez nacieczoną opłucną histopatologicznie najbardziej odpowiadał guzowi z komórek neuroendokrynnych. Badanie immunohistochemiczne wykazało ekspresję chromograniny $(++)$ i synaptofizyny $(+++)$ - charakterystyczną cechę nowotworów neuroendokrynnych. Przeprowadzono również badanie ekspresji antygenu Ki67 (marker aktywności mitotycznej) dochodzącej miejscowo do 10\% komórek. Powyższe badania pozwolity na ustalenie ostatecznego rozpoznania raka neuroendokrynnego wywodzącego się z grasicy.

W badaniach kontrolnych po 2 miesiącach wykazano wznowę procesu nowotworowego: naciek opłucnej śródpiersiowej lewej, worka osierdziowego, przykręgosłupowo po stronie lewej zmianę o charakterze meta naciekającą lewą odnogę uniesionej przepony. Zastosowano 4 kursy leczenia cytostatycznego (karboplatyna/etopozyd). Po zakończeniu chemioterapii wykonano scyntygrafię 


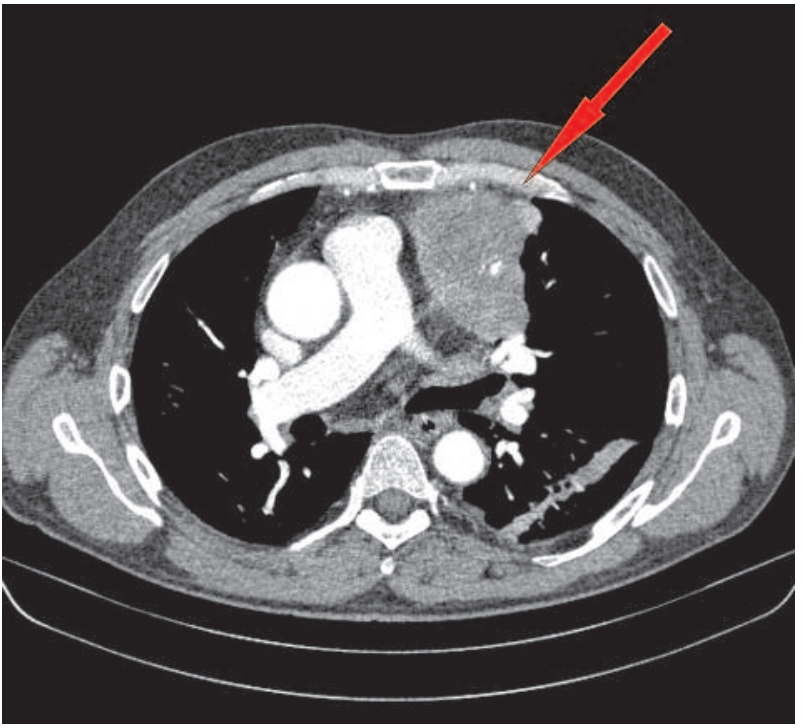

Ryc. 1. Tomografia komputerowa klatki piersiowej. Widoczna hipodensyjna zmiana $(95 \mathrm{~mm} \times 87 \mathrm{~mm} \times 70 \mathrm{~mm}$ ) zlokalizowana po lewej stronie klatki piersiowej w okolicy serca

receptorową z użyciem analogów somatostatyny (99mTc-octreotide scintigraphy), która ujawniła gromadzenie znacznika w podżebrzu lewym, co odpowiadało opisywanemu w ponownym badaniu tomograficznym przerzutowi do ściany klatki piersiowej. W badaniach biochemicznych wykazano zwiększone kilkukrotnie w stosunku do normy wartości serotoniny i kwasu 5-hydroksyindolooctowego (metabolit serotoniny oznaczany w dobowej zbiórce moczu - DZM), które wskazywały na aktywny hormonalnie charakter guza neuroendokrynnego. Stężenie chromograniny A, niespecyficznego markera aktywności choroby, przyjmowało wartości w zakresie górnej granicy normy $(89$ pg/ml, norma laboratoryjna 19-100 pg/ml). Pacjent miał również objawy kliniczne typowe dla zespołu rakowiaka: napadowe zaczerwienienia twarzy, skoki ciśnienia, bóle brzucha, okresowe napadowe duszności. Z uwagi na pozytywny wynik scyntygrafii receptorowej (99mTC-EDDA/HYNIC-TOC - ryc. 2.) oraz wykazanie aktywności hormonalnej zadecydowano o włączeniu leczenia analogami somatostatyny (lanreotyd w dawce 120 mg 1 ampułka domięśniowo co 6 tygodni). W trakcie terapii analogami obserwowano niskie poziomy sodu (121 mmol/l, $123 \mathrm{mmol} / \mathrm{l})$, co skłoniło do rozszerzenia diagnostyki hiponatremii. Obserwowano niskie wartości osmolalności surowicy (225 mOsm/kg wody) z nieadekwatnie zagęszczonym moczem o osmolalności $387 \mathrm{mOsm} / \mathrm{kg}$ wody z wydalaniem sodu w DZM $91 \mathrm{mmol} / \mathrm{l}$, potasu $40 \mathrm{mmol} / \mathrm{l}$. Wykluczono niedoczynność tarczycy i nadnerczy oraz inne przyczyny hiponatremii, takie jak niewydolność serca, nerek czy wątroby.

Pacjent nie stosował żadnej specjalnej diety oraz wypijał przeciętne ilości płynów w ciągu doby. Rozpoznano zespół nieadekwatnego wydzielania wazopresyny (syndrome of inapropriate antidiuretic hormone secretion - SIADH). Zastosowano restrykcję płynów do 1 I na dobę, rozpoczęto doustną i dożylną suplementację soli sodowych, odnotowując częściową poprawę natremii ( $\mathrm{Na} 129 \mathrm{mmol} / \mathrm{l} ; 130 \mathrm{mmol} / \mathrm{l}$ ). W trakcie terapii analogami somatostatyny obserwowano zmniejszenie nasilenia objawów zespołu rakowiaka, lecz

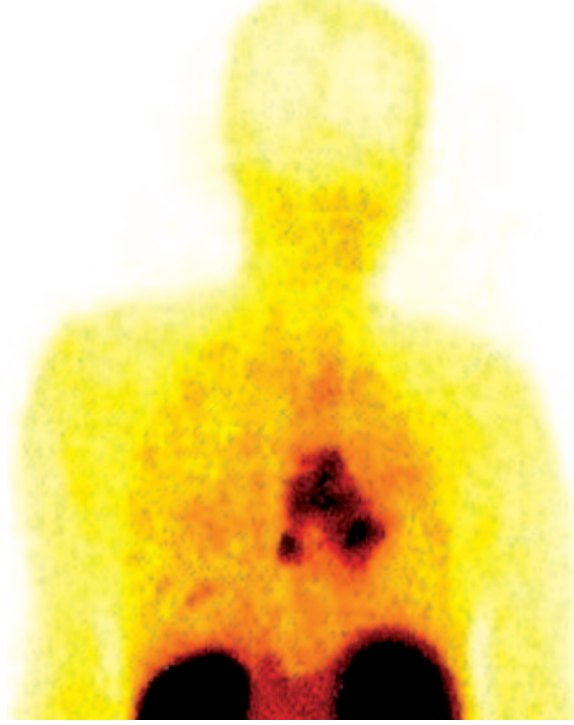

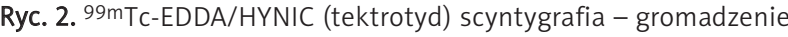
znacznika po lewej stronie klatki piersiowej

z uwagi na progresję choroby nowotworowej pomimo stosowania analogów somatostatyny skierowano pacjenta do Centrum Onkologii, gdzie wdrożono kolejną chemioterapię. Obecnie po zakończeniu drugiego kursu chemioterapii (karboplatyna z etopozydem) pacjent otrzymuje lanreotyd w dawce 120 mg co 6 tygodni. Stan pacjenta jest stabilny. Parametry biochemiczne są w zakresie normy laboratoryjnej. Wielkość zmiany opisywanej w badaniu tomograficznym klatki piersiowej się nie zwiększyła. Mieszana terapia analogami somatostatyny oraz chemioterapia systemowa jest leczeniem zalecanym u chorych z guzami neuroendokrynnymi z udokumentowaną progresją choroby.

\section{Dyskusja}

Zespół nieadekwatnego wydzielania wazopresyny (SIADH) został po raz pierwszy opisany przez Barttera i Schwartza w 1957 r., gdy przedstawiono dwa przypadki raka płuc z hiponatremią i zwiększonym wydalaniem sodu w moczu, które wg autorów prawdopodobnie było związane z nadmiernym wydzielaniem hormonu antydiuretycznego (wazopresyny) [5]. Głównymi wykładnikami zespołu nieadekwatnego wydzielania SIADH są:

- hiponatremia z niskimi wartościami osmolalności osocza (<275 mmol/kg),

- prawidłowa wolemia w badaniu klinicznym,

- nieadekwatnie wysokie wartości osmolalności moczu (> 100 mmol/kg) w stosunku do niskiej osmolalności surowicy z dużą utratą sodu z moczem (> 40 mmol/l).

Należy również wykluczyć inne patologie mogące prowadzić do takiego stanu, jak niedoczynność tarczycy, niedoczynność kory nadnerczy oraz niewydolność serca, wątroby i nerek [6]. Istnieją dodatkowe kryteria diagnostyczne rzadko mające zastosowanie w praktyce:

- test obciążenia wodą: niezdolność do wydalenia z moczem co najmniej $90 \%$ z podanych doustnie $20 \mathrm{ml}$ wody/kg m.c. w ciągu 4 godz. i/lub niemożność rozcieńczenia moczu < $100 \mathrm{mOsm} / \mathrm{kg}$, 
- nieprawidłowo duże wartości stężenia wazopresyny w stosunku do niskiej osmolalności osocza [7].

Najczęstszymi przyczynami SIADH są: nowotwory płuc (w szczególności rak drobnokomórkowy płuc, gdzie występowanie tej patologii dotyczy do 15\% chorych [8]), a także nowotwory przewodu pokarmowego, układu moczowego, chłoniaki, grasiczaki $[9,10]$, choroby płuc (zapalenia płuc, gruźlica, ropień), choroby ośrodkowego układu nerwowego (guzy ośrodkowego układu nerwowego, zapalenie opon mózgowo-rdzeniowych, krwawienia wewnątrzczaszkowe, urazy głowy) oraz leki. Spośród tych ostatnich zwraca się szczególną uwagę na leki przeciwdepresyjne, z których inhibitory zwrotnego wychwytu serotoniny powodują SIADH u ok. 12\% hospitalizowanych pacjentów, szczególnie w wieku > 65 lat [11]. Istnieje też szereg innych leków mogących powodować nieprawidłowe wydzielanie wazopresyny: chinolony, pochodne sulfonylomocznika, cyklofosfamid, a także popularne inhibitory konwertazy angiotensyny. Opisywane są także przypadki objawowej hiponatremii w przebiegu SIADH po zażyciu 3,4-metylenodioksymetamfetaminy znanej jako ecstasy [12]. Istnieją doniesienia o występowaniu tej patologii w przebiegu infekcji HIV, w zespole Guillaina-Barrégo, stwardnieniu rozsianym czy porfirii ostrej przerywanej [6].

Hiponatremia definiowana jako stężenie sodu w surowicy poniżej $135 \mathrm{mmol} / \mathrm{l}$ jest najczęściej spotykanym zaburzeniem elektrolitowym u hospitalizowanych pacjentów [13]. Jest także powszechna w praktyce ambulatoryjnej. Z badań wykonanych przez Sajadieh i wsp. wynika, że częstość występowania łagodnej hiponatremii (135-130) w populacji pacjentów ambulatoryjnych w wieku 55-75 lat bez wywiadu w kierunku chorób krążenia, udaru i nowotworów wynosi 4\% i że to zaburzenie jest niezależnym czynnikiem zgonu lub zawału serca w tej grupie wiekowej [14].

Objawy kliniczne hiponatremii w przebiegu SIADH mogą być bardzo różne w zależności od stopnia niedoboru jonów sodu w przestrzeni pozakomórkowej: od przebiegu bezobjawowego, przez niespecyficzne bóle i zawroty głowy, wymioty, osłabienie, zaburzenia równowagi, do dramatycznie przebiegających zaburzeń neurologicznych - zaburzenia orientacji, oddychania, napady drgawkowe, po śpiączkę i zgon włącznie.

Podstawowe znaczenie w terapii SIADH ma działanie przyczynowe, czyli poszukiwanie i próba eliminacji źródła patologii, co często dostarcza wielu trudności ze względu na różnorodność przyczyn. Objawowo stosuje się suplementację dożylną i doustną chlorku sodu oraz ograniczenie podaży wody do 800-1000 ml na dobę. Nowe perspektywy otwierają waptany - antagoniści receptorów dla wazopresyny. Dziatają na receptory V2 w komórkach cewki zbiorczej nerek, co skutkuje zwiększeniem wydalania wolnej wody przy niezmienionej ilości wydalanych z moczem jonów. W konsekwencji powoduje to wzrost stężenia sodu w surowicy. Jest to o tyle istotne, że wszystkie dotychczas stosowane metody lecznicze nie działają przyczynowo [15].

Guzy neuroendokrynne grasicy występują bardzo rzadko. Zapadalność szacuje się na ok. 1-2 na 10000000 mieszkańców rocznie [14]. Szczyt zachorowań przypada na szóstą dekadę życia z przewagą zachorowań u mężczyzn ( $M: K=3: 1)$ [15]. Pośród wszystkich nowotworów grasicy guzy neuroendokrynne stanowią jedynie ok. 5\% [18]. Objawy najczęściej są niespecyficzne i związane z efektem masy, powodującym zmiany ana- tomiczne w obrębie klatki piersiowej: duszności, kaszel, zespół żyły głównej górnej, lecz mogą pozostać bezobjawowe. W diagnostyce najczęściej stosuje się klasyczne metody radiologiczne (badanie rentgenowskie klatki piersiowej, tomografię komputerową, rezonans magnetyczny). Po uzyskaniu rozpoznania histopatologicznego potwierdzającego charakter neuroendokrynny guza zastosowanie znajduje scyntygrafia receptorowa z użyciem analogów somatostatyny znakowanych radionuklidem. W tej technice wykorzystuje się dobrze znaną cechę tych guzów, jaką jest obecność transbłonowych receptorów dla somatostatyny na ich powierzchni [19]. Jest to niezwykle cenna metoda, która pozwala na uwidocznienie ewentualnych zmian przerzutowych oraz może stanowić wskazanie do leczenia ogólnoustrojowego z użyciem analogów somatostatyny.

Leki te poprzez aktywację odpowiednich receptorów (receptory dla somatostatyny typu 2 i 5) hamują proliferację komórkową, angiogenezę oraz aktywność hormonalną nowotworu, a także indukują apoptozę [20].

W leczeniu zastosowanie znajdują także analogi somatostatyny znakowane radionuklidem emitującym promieniowanie beta, na przykład 90Y-(DOTA0,Tyr3)-octreotate lub 177Lu-DOTA0,Tyr3)-octreotate. W przypadkach nisko zróżnicowanych guzów o wysokim indeksie proliferacyjnym zastosowanie znajduje chemioterapia w różnych schematach leków cytostatycznych. Nowe perspektywy otwiera zastosowanie nowych leków w terapii guzów neuroendokrynnych: inhibitory angiogenezy (np. bewacizumab), inhibitory kinazy tyrozynowej (np. sunitinib), pochodna rapamycyny (ewerolimus), które na razie pozostają w fazie badań klinicznych [21]. Przeżywalność zależy przede wszystkim od stopnia dojrzałości histologicznej nowotworu, stopnia jego zaawansowania w momencie rozpoznania oraz możliwości zastosowania pierwszorzutowej metody leczenia, jaką jest działanie chirurgiczne. Istnieją doniesienia, że współistniejąca endokrynopatia pogarsza w sposób istotny 5-letnią przeżywalność w odniesieniu do sytuacji bez zaburzeń hormonalnych (35\% vs 65\%) [4].

\section{Podsumowanie}

Hiponatremia to najczęściej opisywane zaburzenie elektrolitowe u hospitalizowanych pacjentów, z czego SIADH opisywany jest jako jej najczęstsza przyczyna [6]. Postępowanie diagnostyczne $w$ tego typu zaburzeniu może nasuwać szereg trudności ze względu na różnorodność przyczyn. Opisany w niniejszej pracy przypadek skłania do poszerzenia zakresu potencjalnych przyczyn tej patologii o niespotykaną dotychczas w literaturze przyczynę choroby.

\section{Piśmiennictwo}

1. Moran CA, Suster S. Spindle-cell neuroendocrine carcinoma of the thymus: a clinicopathologic and immunohistochemical study of seven cases. Mod Pathol 1999; 12: 587-91.

2. Jensen RT, Norton JA. Carcinoid tumors and carcinoid syndrome. Cancer: Principles and practice of oncology. 5th edition. DeVita VT, Hellman S, Rosenberg SA (eds.). J.B Lippincott Company, Philadelphia 1997: 1704-23.

3. Rosai J, Higa E. Mediastinal endocrine neoplasm, of probable thymic origin, related to carcinoid tumor: clinicopathologic study of 8 cases. Cancer 1972; 29: 1061-74. 
4. Ruffini E, Oliaro A, Novero D, Campisi P, Filosso PL. Neuroendocrine tumors of the thymus. Thorac Surg Clin 2011; 21: 13-23.

5. Schwartz WB, Bennet W, Curelop S, Bartter FC. A syndrome of renal sodium loss and hyponatremia probably resulting from inappropriate secretion of antidiuretic hormone. Am J Med 1957; 23: 529-42.

6. Hannon MJ, Thomson CJ. The syndrome of inappropriate antidiuretic hormone: prevalence, causes and consequences. Eur J Endocrinol 2010; 162: S5-S12.

7. Smith MD, McKenna K, Thomson C. Hyponatremia. Clinical Endocrinology 2000; 52: 667-8.

8. Sorensen JB, Andersen MK, Hansen HH. Syndrome of innapropriate secretion of antidiuretic hormone (SIADH) in malignant disease. J Intern Med 1995; 238: 97-110.

9. Walid MS, Troup EC, Robinson JS Jr. Brain metastasis from thymic carcinoma in association with SIADH and pituitary enlargement: a case report. South Med J 2008; 101: 764-6.

10. Galesic K, Krizanac S, Vrkljan M, Ljubanovic D. Syndrome of inappropriate secretion of antidiuretic hormone due to malignant thymoma. Nephron 2002; 91: 752-4.

11. Bouman WP, Pinner G, Johnson H. Incidence of selective serotonin reuptake inhibitor induced hyponatremia due to syndrome of inappropriate antidiuretic hormone secretion in the elderly. Int J Geriatr Psychiatry 1998; 13: 113-5.

12. Holden R, Jackson MA. Near-fatal hyponatremic coma due to vasopressin over-secretion after 'ecstasy' (3,4-MDMA). Lancet 1996; 347: 105.

13. Baran D, Hutchison TA. Outcome of hyponatraemia in general hospital population. Clinical Nephrology 1984; 22: 72-6.

14. Sajadieh A, Binici Z, Mouridsen MR, Nielsen OW, Hansen JF, Haugaard SB. Mild hyponatremia carries a poor prognosis in community subject. Am J Med 2009; 122: 679-86.

15. Olszewski W, Głuszek J. Vasopressin antagonists in treatment of hyponatremia. Pol Arch Med Wewn 2007; 117: 356-62.

16. Oberg K, Jelic S. Neuroendocrine bronchial and thymic tumors: ESMO clinical recommendation for diagnosis, treatment and follow-up. Ann Oncol 2008; 19: 102-3.

17. Dusmet ME, McKneally MF. Pulmonary and thymic carcinoid tumors. World J Surg 1996; 20: 189-95.

18. Shimosato Y, Mukai K. Tumors of the madiastinum. 3rd ed. Washington, DC: Armed Forces Institute of Pathology 1995.

19. Kaltas G, Rockall A, Papadogias D, Reznek R, Grossman AB. Recent advances in radiological and radionuclide imaging and therapy of endocrine tumors. Eur J Endocrinol 2004; 151: 15-27.

20. Pawlikowki M. Receptory somatostatynowe w guzach neuroendokrynnych. Guzy neuroendokrynne układu pokarmowego. Kos-Kudła B (ed.). Via medica, Gdańsk 2010; 25-32.

21. Phan AT, Oberg K, Choi J, Harrison LH, Hassan MM, Strosberg JR, Krenning EP, Kocha W, Woltering EA, Maples WJ. NANETS Consensus guideline for diagnosis and management of neuroendocrine tumors. Welldifferentiated neuroendocrine Tumors of the thorax (Includes lung and thymus). Pancreas 2010; 39: 784-98.

\section{Adres do korespondencji}

dr med. Paweł Gut

Katedra i Klinika Endokrynologii,

Przemiany Materii i Chorób Wewnętrznych

Uniwersytet Medyczny im. K. Marcinkowskiego w Poznaniu

ul. Przybyszewskiego 49

60-355 Poznań

tel. 607392922

e-mail: gutpj@poczta.onet.pl 